\title{
Bronchial hyperresponsiveness and airway inflammation markers in nonasthmatics with allergic rhinitis
}

\author{
R. Polosa, I. Ciamarra, G. Mangano, G. Prosperini, M.P. Pistorio, C. Vancheri, N. Crimi
}

\begin{abstract}
Bronchial hyperresponsiveness and markers of airway inflammation in nonasthmatics with allergic rhinitis. R. Polosa, I. Ciamarra, G. Mangano, G. Prosperini, M.P. Pistorio, C. Vancheri, N. Crimi. (C)ERS Journals Ltd 2000.

ABSTRACT: Bronchial hyperresponsiveness (BHR) is a characteristic feature of asthma which is often associated with airways inflammation. However, some patients with allergic rhinitis and no clinical evidence of asthma also exhibit BHR. This study therefore investigated whether inflammatory cell infiltrate is present in the induced sputum of nonasthmatic subjects with allergic rhinitis during the pollen season and examined its relationship with airway hyperresponsiveness to inhaled methacholine and adenosine 5'-monophosphate (AMP).

Twenty subjects (12 allergic rhinitis, eight nonallergic controls) underwent methacholine and AMP challenge and sputum induction with hypertonic saline on separate days. Cell differentials were calculated from whole sputum samples.

A significantly greater number of eosinophils was found in the sputum of nonasthmatic subjects with allergic rhinitis compared to that of nonallergic controls, their median (range) percentages being $17.5(4-47)$ and $1.5(0-5)(p<0.001)$ respectively. Although sputum eosinophilia failed to be significantly associated with methacholine responsiveness $(r s=-0.50 ; p=0.095)$, the provocative concentration of $A M P$ causing a $\mathbf{2 0 \%}$ fall in forced expiratory volume in one second correlated strongly and significantly with the absolute number of eosinophils $(r s=-0.73 ; p=0.007)$. Eosinophil cationic protein levels in the sputum of rhinitic subjects were significantly elevated compared to controls and correlated with eosinophil number $(r s=0.67 ; p=0.017)$.

These findings support the view that bronchial eosinophilia alone is insufficient to cause asthmatic symptoms. Diverse agonists for assessing bronchial hyperresponsiveness are selectively associated with airway inflammation in allergic rhinitis. Eur Respir J 2000; 15: 30-35.
\end{abstract}

Istituto Malattie Apparato Respiratorio, University of Catania, 95125 Catania, Italy

Correspondence: R. Polosa

Istituto Malattie Apparato Respiratorio

University of Catania

Via Passo Gravina 187

95125 Catania, Italy

Fax: 39095330707

\section{Keywords: Adenosine}

airway hyperresponsiveness

allergic rhinitis

eosinophils

induced sputum

methacholine

\section{Received: April 131999}

Accepted after revision September 291999

These studies were supported by a research grant of the University of Catania (Grant 60\%).
The role of chronic bronchial inflammation in asthma is widely appreciated, and airway eosinophilic inflammation is indicated as one of the most important factors in the pathogenesis of this disease [1]. The importance of airway eosinophilia as a major marker of disease activity is well established [2-5]. Other than being one of the key cells responsible for the development of many of the pathological features of asthma, the eosinophil is often associated with the presence of bronchial hyperresponsiveness (BHR), a distinctive characteristic of the disease [6]. Besides methacholine and histamine, asthmatic subjects also have exaggerated airway responses to the purine nucleoside adenosine [7]. Methacholine- and histamine-induced bronchoconstriction are likely to be due primarily to a "direct" effect of these agonists on specific receptors on airway smooth muscle. In contrast, the underlying mechanism of bronchoconstriction induced by adenosine is mainly "indirect", involving mast cell mediator release [8].

However, it is known that BHR is also present in patients with allergic rhinitis and no clinical evidence of asthma [9-12]. Bronchoalveolar lavage (BAL), bronchial biopsy and sputum studies have provided evidence that patients with seasonal allergic rhinitis may demonstrate inflammatory processes in the lower airways, with eosinophils frequently being observed [13-15]. These findings are suggestive of subclinical inflammatory changes within the lower airways in subjects with allergic rhinitis, but their relevance to the study of asthma is not clear. There are strong clinical and epidemiological associations between allergic rhinitis and extrinsic asthma; allergic rhinitis often precedes the onset of clinical asthma and could serve as a risk factor for the development of asthma [12, 16, 17].

Little is known about the critical factors that determine BHR in subjects with allergic rhinitis. Therefore, evidence was sought in induced sputum for the presence of an inflammatory cell infiltrate in 12 nonasthmatic subjects with allergic rhinitis and its relationship with airway hyperresponsiveness to two well-defined bronchoconstrictor agonists, methacholine and adenosine 5 '-monophosphate (AMP), examined. Bronchial challenge and sputum induction with hypertonic saline were also performed in eight nonallergic healthy controls well-defined bronchoconstrictor agonists, methacholine and adenosine.

\section{Methods}

\section{Subjects}

The study population consisted of 12 nonasthmatic subjects (two female, 10 male) with seasonal allergic rhinitis and eight nonallergic control subjects (three female, five 
male) (table 1). Subjects with allergic rhinitis had a characteristic history of seasonal allergic rhinitis (rhinorrhoea, nasal itch, sneezing, nasal obstruction) and positive skinprick tests results ( $>3 \mathrm{~mm}$ weal response) to Parietaria pollen only, the most common inhalant allergen in Sicily [18] and none had ever received immunotherapy or topical corticosteroids. All were controlled using nasal topical decongestants and oral antihistamines as required. Antihistamines were withheld for $\geq 3$ days prior to each visit, but subjects were allowed to continue their nasal topical decongestants as usual. None of them had a present or past history of asthma (wheezing, dyspnoea, chest tightness, chronic cough). At least two specialists in allergic diseases at the authors' clinic agreed that they did not have any clinical history or symptoms suggestive of asthma. They were specifically selected on the basis of positive responses to inhaled methacholine and AMP. Nonallergic control subjects had no history of asthma, chronic rhinitis, atopic eczema or other relevant disease, and their skin-prick test results were negative. All 20 subjects were nonsmokers, and their baseline forced expiratory volume in one second (FEV1) was $>85 \%$ of the predicted value (table 1). None of the subjects studied had experienced a respiratory tract infection for $\geq 6$ weeks before or during the study. The study was approved by the local hospitals ethical committee and all the subjects gave their consent.

\section{Study design}

The study consisted of three visits to the authors' department during the Parietaria pollen season (March-June

Table 1. - Characteristics of the subjects studied

\begin{tabular}{|c|c|c|c|c|c|}
\hline $\begin{array}{l}\text { Subject } \\
\text { No. }\end{array}$ & $\begin{array}{l}\text { Age } \\
\text { yrs }\end{array}$ & Sex & $\begin{array}{c}\text { Baseline } \\
\text { FEV } 1 \\
\% \text { pred }\end{array}$ & $\begin{array}{l}\text { PC20 M } \\
\mathrm{mg} \cdot \mathrm{mL}^{-1}\end{array}$ & $\begin{array}{c}\mathrm{PC} 20 \text { AMP } \\
\mathrm{mg} \cdot \mathrm{mL}^{-1}\end{array}$ \\
\hline
\end{tabular}

\begin{tabular}{|c|c|c|c|c|c|}
\hline \multicolumn{6}{|c|}{ Rhinitic subjects } \\
\hline 1 & 22 & M & 112 & 5.2 & 90.4 \\
\hline 2 & 35 & $\mathrm{~F}$ & 108 & 3.6 & 683.4 \\
\hline 3 & 27 & M & 99 & 2.4 & 168.6 \\
\hline 4 & 18 & M & 87 & 10.9 & 294.1 \\
\hline 5 & 26 & M & 89 & 53.8 & 732.6 \\
\hline 6 & 24 & M & 124 & 5.7 & 163.4 \\
\hline 7 & 18 & M & 96 & 30.5 & 600.5 \\
\hline 8 & 23 & M & 97 & 1.5 & 52.7 \\
\hline 9 & 32 & M & 100 & 2.5 & 85.4 \\
\hline 10 & 20 & M & 112 & 35.9 & 666.7 \\
\hline 11 & 29 & M & 129 & 2.0 & 196.9 \\
\hline 12 & 27 & $\mathrm{~F}$ & 95 & 3.7 & 120.0 \\
\hline $\operatorname{Mean} \pm \mathrm{SD}$ & $25.1 \pm 5.3$ & & $104 \pm 13.0$ & $\begin{array}{c}6.4 \\
(1.5-53.8)\end{array}$ & $\begin{array}{c}223.6 \\
(52.7-732.6)^{*}\end{array}$ \\
\hline \multicolumn{6}{|c|}{ Nonallergic controls } \\
\hline 1 & 35 & $\mathrm{M}$ & 114 & $>64$ & $>800$ \\
\hline 2 & 27 & M & 96 & $>64$ & $>800$ \\
\hline 3 & 25 & $\mathrm{~F}$ & 115 & $>64$ & $>800$ \\
\hline 4 & 30 & M & 90 & $>64$ & $>800$ \\
\hline 5 & 25 & $\mathrm{~F}$ & 112 & $>64$ & $>800$ \\
\hline 6 & 24 & M & 92 & $>64$ & $>800$ \\
\hline 7 & 22 & M & 128 & $>64$ & $>800$ \\
\hline 8 & 18 & $\mathrm{~F}$ & 110 & $>64$ & $>800$ \\
\hline $\operatorname{Mean} \pm$ SD & $25.8 \pm 5.1$ & & $107 \pm 13.2$ & $>64^{*}$ & $>800^{*}$ \\
\hline
\end{tabular}

*: geometric mean (range); FEV1: forced expiratory volume in one second; PC20: provocative concentration of agonist causing a $20 \%$ fall in FEV1; MCh: methacholine; AMP: adenosine 5'monophosphate; M: male; F: female.
1996), all of which were at the same time of day (09:00 h). On the first day, subjects attended the laboratory to undergo a methacholine challenge test to determine the provocative concentration of agonist causing a $20 \%$ fall in FEV1 (PC20). Two days later, sputum induction with hypertonic saline was carried out. The expectorated sputum was immediately collected and processed. On the final visit (5-7 days later), subjects attended the laboratory and underwent adenosine 5'-monophosphate (AMP) challenge to determine the PC20 to AMP.

\section{Bronchial provocation}

Methacholine chloride and AMP (Sigma Chemical Co., St Louis, MO, USA) were dissolved in normal saline to produce doubling concentrations, ranging $0.5-64 \mathrm{mg} \cdot \mathrm{mL}^{-1}$ for methacholine and $12.5-800 \mathrm{mg} \cdot \mathrm{mL}^{-1}$ for AMP, and immediately used for bronchial challenge. The solutions were administered as aerosols generated from a starting volume of $3 \mathrm{~mL}$ in a disposable Inspiron Minineb (C.R. Bard International, Sunderland, UK) driven by compressed air at $8 \mathrm{~L} \cdot \mathrm{min}^{-1}$. Patients inhaled the aerosolized solutions in five breaths from functional residual capacity to total lung capacity via a mouthpiece.

FEV1 was measured using a dry wedge spirometer (Vitalograph, Buckingham, UK). After a 15-min rest, three consecutive baseline measurements of FEV1 were made at intervals of $2 \mathrm{~min}$ and the highest result recorded. Challenges were preceded by inhalation of normal saline and only subjects in whom this caused $a<10 \%$ decrease from baseline FEV1 were studied. After challenge with saline, doubling concentrations of methacholine or AMP were administered. FEV1 was measured at 1 and 3 min after administration of each concentration of agonist and the highest of two values recorded for analysis. The challenges were discontinued when FEV1 had fallen by $>20 \%$ of the post-saline value. The bronchial response to the inhaled agonists was expressed as the PC20, which was derived by linear interpolation from the concentration/response curve constructed on a logarithmic scale by plotting the percentage change in FEV1 from the post-saline value against the cumulative concentration of agonist administered.

\section{Sputum induction}

Induction was performed according to the method described by Lous et al. [19]. Briefly, subjects inhaled hypertonic saline $(4.5 \%)$ aerosolized using an ultrasonic nebulizer (UltraNeb 99; DeVilbiss, Feltham, UK) with output set at $3 \mathrm{~mL} \cdot \mathrm{min}^{-1}$ The subjects wore a nose clip and quietly inhaled aerosol for up to four consecutive 5min periods. After each inhalation, the subjects rinsed their mouth with water and dried it with tissue paper to minimize contamination with saliva. They then expectorated the sputum into a Petri dish, which was immediately placed on ice until processing. The FEV1 was measured after each 5-min period for safety reasons.

\section{Sputum processing and analysis}

Whole sputum was transferred into 50-mL polypropylene tubes (Becton Dickinson, Abingdon, UK), weighed 
and an equal weight of $0.01 \mathrm{M}$ dithioerythritol (Fluka, Gillingham, UK) solution added to solubilize the mucus. Specimens were then agitated on a vortex mixer for $10 \mathrm{~s}$, rocked for $30 \mathrm{~min}$ at room temperature $\left(\sim 22^{\circ} \mathrm{C}\right)$ and again agitated on a vortex mixer for $10 \mathrm{~s}$. They were then filtered through a $70-\mu \mathrm{m}$ strainer (Becton Dickinson) and the collected fluid centrifuged for $10 \mathrm{~min}$ at $400 \times g$ at $4 \mathrm{C}$. The super-natants were removed and stored at $-20 \mathrm{C}$. The cell pellets were resuspended in $1 \mathrm{~mL}$ of phosphate-buffered saline $\left(6.5 \mathrm{~g} \cdot \mathrm{L}^{-1} \mathrm{NaCl}, 1.28 \mathrm{~g} \cdot \mathrm{L}^{-1} \mathrm{Na}_{2} \mathrm{HPO}_{4}, 1.96 \mathrm{~g} \cdot \mathrm{L}^{-1}\right.$ $\mathrm{NaH}_{2} \mathrm{PO}_{4}$; $\mathrm{pH} 7.4$ ) not containing $\mathrm{Ca}^{2+}$ and $\mathrm{Mg}^{2+}$ and viable cells counted in a haemocytometer. Only samples in which squamous cells comprised $<30 \%$ of total cells were considered satisfactory for analysis. Differential counting was carried out on cytospins stained with May-Grünwald Giemsa on 600 cells (excluding squamous cells). Slides were coded and examined by one investigator and counts expressed as a percentage of the number of total cells and as absolute counts. Eosinophil cationic protein (ECP) levels were measured in duplicate using a commercially available fluorometric enzyme immunoassay (Pharmacia, Uppsala, Sweden) with a sensitivity of $2 \mathrm{ng} \cdot \mathrm{mL}^{-1}$.

\section{Data analyses}

The PC20 to methacholine and AMP were logarithmically transformed to normalize their distribution and expressed as geometric mean (range). The relationship between the $\mathrm{PC}_{20}$ to methacholine and the $\mathrm{PC}_{20}$ to AMP was studied by least squares linear regression. Inflammatory cell counts in sputum were shown as a percentage of total cell counts (excluding squamous cells) and as absolute cell numbers per weight of sputum. As cell counts in induced sputum are not normally distributed, these were expressed as median (range). Comparisons of sputum variables between groups were performed using the Mann-Whitney Utest for unpaired data.

For correlation analyses of sputum variables and airway responses to AMP and methacholine, Spearman's rankorder test was used. A p-value of $<0.05$ was considered to indicate statistical significance.

\section{Results}

The geometric mean (range) $\mathrm{PC} 20$ to methacholine and AMP were $6.4 \mathrm{mg} \cdot \mathrm{mL}^{-1}\left(1.5-53.8 \mathrm{mg} \cdot \mathrm{mL}^{-1}\right)$ and 223.6 $\mathrm{mg} \cdot \mathrm{mL}^{-1}\left(52.7-732.6 \mathrm{mg} \cdot \mathrm{mL}^{-1}\right)$, respectively, in the nonasthmatic patient with allergic rhinitis (table 1). A significant correlation was observed between the $\mathrm{PC}_{20}$ to methacholine and the PC20 to AMP ( $\mathrm{r}=0.77, \mathrm{p}=0.004)$.

Sputum induction was well tolerated in all the subjects studied. A significantly greater number of eosinophils was found in the sputum of nonasthmatic subjects with allergic rhinitis compared to that in nonallergic controls, their median (range) percentage counts being 17.5 (4-47) and 1.5 $(0-5)(p<0.001)$, respectively (table 2 , fig. 1$)$. No significant differences were observed for other cell types between nonallergic controls and subjects with allergic rhinitis with the exception of macrophages, their median (range) percentage counts being 42.0 (26-76) and 70.5 (63-75) $(\mathrm{p}=0.002)$ in allergic rhinitics and controls, respectively (table 2, fig. 1). Bronchial responsiveness to either agonist did not correlate with sputum neutrophil, lympho-
Table 2. - Total and percentage cell counts in the sputum of the subjects studied

\begin{tabular}{lcccccc}
\hline $\begin{array}{l}\text { Subject } \\
\text { No. }\end{array}$ & $\begin{array}{c}\text { Total cells } \\
10^{3} \text { cells } \cdot \mathrm{g}^{-1}\end{array}$ & $\begin{array}{c}\text { Macro } \\
\%\end{array}$ & $\begin{array}{c}\text { Lym } \\
\%\end{array}$ & $\begin{array}{c}\text { Neu } \\
\%\end{array}$ & $\begin{array}{c}\text { Eos } \\
\%\end{array}$ & $\begin{array}{c}\text { ECP } \\
\text { ng.mL }\end{array}$ \\
\hline Rhinitic subjects & & & & & \\
1 & 2,000 & 37 & 5 & 7 & 47 & 643.3 \\
2 & 390 & 76 & 2 & 16 & 4 & 16.5 \\
3 & 230 & 62 & 4 & 13 & 19 & 123.9 \\
4 & 68 & 29 & 1 & 57 & 12 & 20.0 \\
5 & 195 & 34 & 4 & 53 & 7 & 18.5 \\
6 & 517 & 26 & 4 & 50 & 18 & 44.8 \\
7 & 427 & 30 & 3 & 56 & 11 & 100.1 \\
8 & 397 & 48 & 8 & 5 & 37 & 334.9 \\
9 & 637 & 44 & 7 & 15 & 31 & 90.7 \\
10 & 1155 & 59 & 4 & 28 & 7 & 462.8 \\
11 & 772 & 56 & 4 & 4 & 36 & 224.0 \\
12 & 717 & 40 & 5 & 35 & 17 & 20.9 \\
Median & 472 & 42.0 & 4.0 & 22.0 & 17.5 & 95.4 \\
Range & $68-2000$ & $26-76$ & $1-8$ & $4-57$ & $4-47$ & $16.5-643.3$ \\
Nonallergic controls & & & & & \\
1 & 2000 & 74 & 3 & 22 & 0 & 8.5 \\
2 & 2450 & 68 & 4 & 26 & 0 & 10.0 \\
3 & 220 & 75 & 4 & 18 & 2 & 7.4 \\
4 & 450 & 73 & 1 & 21 & 5 & 58.7 \\
5 & 770 & 71 & 11 & 15 & 0 & 6.6 \\
6 & 480 & 70 & 5 & 23 & 1 & 15.9 \\
7 & 630 & 63 & 8 & 25 & 2 & 79.0 \\
8 & 810 & 67 & 6 & 24 & 2 & 71.2 \\
Median & 700 & 70.5 & 4.5 & 22.5 & 1.5 & 13.0 \\
Range & $200-2450$ & $63-75$ & $1-11$ & $15-26$ & $0-5$ & $6.6-79.0$ \\
\hline
\end{tabular}

Macro: macrophage; Lym: lymphocytes; Neu: neutrophils; Eos: eosinophils; ECP: eosinophil cationic protein.

cyte, and macrophage numbers. Although sputum eosinophilia failed to be significantly associated with methacholine airway responsiveness $(\mathrm{r} s=-0.50, \mathrm{p}=0.095)$ (fig. $2 \mathrm{a}$ ), there was a strong and significant negative correlation between the PC20 to AMP and the absolute number of eosinophils in the sputum ( $\left.r_{s}=-0.73, p=0.007\right)$ (fig. $2 b$ ).

ECP levels measured in the sputum supernatant of nonasthmatic subjects with allergic rhinitis were significantly higher than those of controls, their median (range) concentrations being $95.4 \mathrm{ng} \cdot \mathrm{mL}^{-1}(16.5-643.3)$ and $13.0 \mathrm{ng} \cdot \mathrm{mL}^{-1}$ $(6.6-79.0)(\mathrm{p}<0.001)$, respectively (table 2$)$. The concentration of ECP in the sputum correlated with the absolute number of eosinophils ( $\mathrm{r}=0.67, \mathrm{p}=0.017$ ), but no significant association was found between the con-centration of ECP in sputum and airway responsiveness to any of the agonists tested.

\section{Discussion}

In the present study, it has been shown that a large number of eosinophils is present in the sputum of nonasthmatic subjects with allergic rhinitis to Parietaria pollen during a period of natural exposure. Eosinophil counts in the sputum of subjects with allergic rhinitis were approximately 12-fold higher than those of nonallergic controls (studied at the same time). In addition, the number of macrophages was lower in subjects with allergic rhinitis compared to nonallergic controls. It was also observed that airway responsiveness to AMP is more strongly related to sputum eosinophilia than is that to methacholine.

The role of chronic bronchial inflammation in asthma is widely appreciated, and airway eosinophilic inflammation 


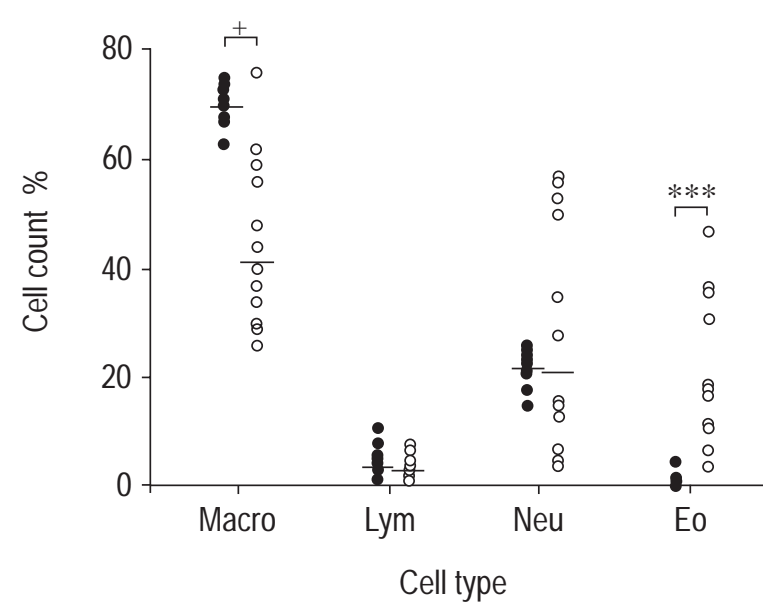

Fig. 1. - Differential counts of macrophages (Macro), lymphocytes (Lym), neutrophils (Neut) and eosinophils (Eos) in induced sputum obtained from nonallergic controls $(\mathcal{)}$ ) and nonasthmatics subjects with seasonal allergic rhinitis $(O)$ during the season. Horizontal bars represent medians; ${ }^{+}: \mathrm{p}=0.002 ; * * *: \mathrm{p}<0.001$, controls versus allergic rhinitics (Mann-Whitney U-test for unpaired data)

is often associated with the presence of BHR [6]. Normally, subjects with allergic rhinitis exhibit relatively low levels of nonspecific BHR. In the rhinitic subjects studied, the PC20 to methacholine and AMP were close to the asthmatic range. In particular, two patients (Nos. 8 and 9) had very low PC20 to both methacholine and AMP, sputum eosinophilia and high levels of ECP. However, by further reviewing their case histories and measuring their response to inhaled salbutamol, the possibility of unrecognized asthma or cough-variant asthma was again excluded. It should be noted that the rhinitic subjects were studied during the pollen season and were specifically selected from a larger pool of patients on the basis of their positive response to inhaled methacholine and AMP.

Although allergic rhinitis and asthma are closely related disorders that commonly occur together, very little is known about inflammatory features in the bronchial airways of subjects with allergic rhinitis and no evidence of asthma. BAL and bronchial biopsy studies have shown that subjects with allergic rhinitis may exhibit inflammatory changes of the airways [13, 14]. In line with these observations, FORESI et al. [15] have recently demonstrated that a significant number of eosinophils and metachromatic cells may be present in induced sputum from subjects with seasonal allergic rhinitis. However, their findings are at variance with those of PIN et al. [20] and SPANEvELLo et al. [21], who failed to show a significant difference in the percentage of eosinophils in induced sputum between individuals with seasonal allergic rhinitis (studied out of the pollen season) and healthy controls. The reasons for such discrepancies might be related to diversity in the disease activity in the subjects studied or to important differences in methodology and study protocol. By studying the present subjects with allergic rhinitis to Parietaria pollen during a period of natural exposure to their sensitizing allergen, a substantial number of eosinophils was found in their sputum. It may be speculated that exposure of the bronchial epithelium to aeroallergens may promote airway eosinophilia through immunoglobulinE-dependent pathways. In addition, allergens may directly alter epithelial cell function through induction of a stress response via stimulation of proteinase-activated receptors [22] or by generation of reactive oxygen with activation of pro-inflammatory transcription factors [23] with subsequent release of eosinophil chemoattractants and survival-enhancing factors such as eotaxin, interleukin (IL)-8, granulocytemacrophage colony-stimulating factor, and IL-5 [24-26].

The dissociation between methacholine and AMP responsiveness and markers of allergic inflammation has also been addressed in a recent study of allergen avoidance in children with allergic asthma [27]. The discrepancy may lie in the difference in their mechanisms of bronchoconstrictor effect, methacholine directly contracting airway smooth muscle and AMP releasing mast cell-derived mediators [8]. The observed relationship between sputum eosinophils and the PC20 to AMP may also be explained by considering that eosinophil-derived cytokines stimulate the epithelium to release factors promoting mast cell chemotaxis and maturation [28]. Another possible interpretation of the selective influence of sputum eosinophils on AMP responsiveness might lie in the release of their granular contents causing airway epithelial damage [3,29]. Damage to the epithelium might selectively enhance sensory nerve stimulation by AMP (but not methacholine), resulting in the release of spasmogenic neuropeptides by way of an axon reflex [30].
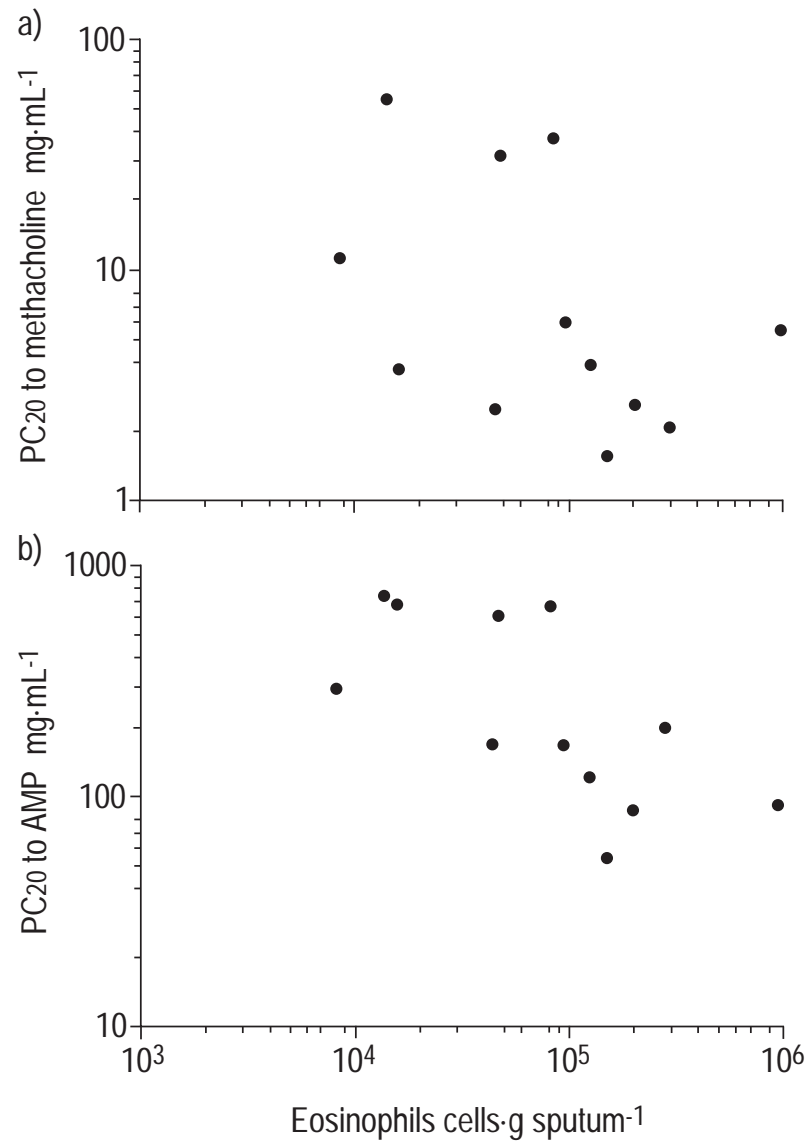

Fig. 2. - Correlation between the number of eosinophils in the sputum and the provocative concentration of agonist causing a $20 \%$ fall in forced expiratory volume in one second $(\mathrm{PC} 20)$ to a) methacholine $\left(\mathrm{r}_{\mathrm{s}}=-0.50\right.$, $\mathrm{p}=0.095)$; and $\mathrm{b})$ adenosine $\mathrm{S}^{\prime}$-monophosphate (AMP) $(\mathrm{rs}=-0.73 ; \mathrm{p}=$ $0.007)$ in nonasthmatic subjects with allergic rhinitis $(\mathrm{n}=12)$. The strength of the association was analysed using Spearman's rank-order test. 
Whilst the present findings indicate that airway responsiveness to AMP is related to the degree of eosinophilic infiltration, the lack of an association with ECP levels would suggest that the mechanisms involve other eosinophil mediators (e.g. major basic protein), which may contribute to the enhanced airway responses to AMP. In addition, the concentration of ECP in sputum may reflect poorly the extent of eosinophil activation that occurs deep within the airways mucosa, thus accounting for the lack of correlation between sputum ECP levels and airway responsiveness to AMP.

Whatever the mechanisms linking the airway eosinophilia and bronchial hyperresponsiveness to AMP, there is no doubt that subclinical inflammatory changes within the lower airways are present in subjects with allergic rhinitis (even in the absence of clinical asthma). Compared to recently published data in mild asthma [31], the number of eosinophils in the sputum of rhinitic subjects studied during the pollen season is considerably elevated. Although the present findings indicate that bronchial eosinophilia alone is insufficient to cause asthmatic symptoms, it is difficult to establish whether subjects with allergic rhinitis and eosinophilic inflammation might be at increased risk of the development of asthma over subsequent years. Long-term prospective studies of patients with allergic rhinitis, including assessments of sputum eosinophilia and bronchial responsiveness (particularly to indirect stimuli), will be critical in answering this question.

A significantly lower macrophage count was also found in subjects with allergic rhinitis and this agrees with a number of studies in asthmatics $[19,32]$. Stimulation of human eosinophils may release large quantities of macrophage migration inhibitory factor [33], which may decrease the number of macrophages. Although very little is known about the modulatory role of macrophages in airway inflammation, this observation is of interest and merits further investigation.

\section{References}

1. Djukanovic R, Roche WR, Wilson JW, et al. Mucosal inflammation in asthma. Am Rev Respir Dis 1990; 142: 434-457.

2. Beasley R, Roche WR, Roberts JA, Holgate ST. Cellular events in the bronchi in mild asthma and after bronchial provocation. Am Rev Respir Dis 1989; 139: 806-817.

3. Bousquet J, Chanez P, Lacoste JY, et al. Eosinophilic inflammation in asthma. N Engl J Med 1990; 323: 10331039 .

4. Laitinen LA, Laitinen A, Haahtela T. A comparative study of the effects of an inhaled corticosteroid, budesonide and a $\beta_{2}$-agonist, terbutaline, on airway inflammation in newly diagnosed asthma: a randomized, double-blind, parallel group controlled trial. J Allergy Clin Immunol 1992; 90: $32-42$.

5. Djukanovic R, Wilson JW, Britten KM, et al. Effect of an inhaled corticosteroid on airway inflammation and symptoms in asthma. Am Rev Respir Dis 1992; 145: 669-674.

6. Holgate ST, Roche W, Church MK. The role of the eosinophil in asthma. Am Rev Respir Dis 1991; 143: 566570.

7. Polosa R, Holgate ST. Adenosine bronchoprovocation: a promising marker of allergic inflammation in asthma? Thorax 1997; 52: 919-923.
8. Polosa R, Ng WH, Crimi N, et al. Release of mast cellderived mediators after endobronchial adenosine challenge in asthma. Am J Respir Crit Care Med 1995; 151: 624-629.

9. Stevens WJ, Vermeire PA. Bronchial responsiveness to histamine and allergen in patients with asthma, rhinitis, cough. Eur J Respir Dis 1980; 61: 203-212.

10. Townley RG, Ryo UY, Kolotkin BM, Kang B. Bronchial sensitivity to methacholine in current and former asthmatic and allergic rhinitis patients and control subjects. $J$ Allergy Clin Immunol 1975; 56: 429-442.

11. Cockcroft DW, Killian DN, Mellon JJA, Hargreave FE. Bronchial reactivity to inhaled histamine: a method and clinical survey. Clin Allergy 1977; 7: 235-243.

12. Crimi $\mathrm{N}$, Palermo $\mathrm{F}$, Oliveri $\mathrm{R}$, et al. Influence of asthmatic and rhinitic symptomatology and duration on bronchial responsiveness to histamine. Int J Tiss React 1987; 9: 515-520.

13. Bradley BL, Azzawi M, Jacobson M, et al. Eosinophils, T-lymphocytes, mast cells, neutrophils and macrophages in bronchial biopsy specimens from atopic subjects with asthma: comparisons with biopsy specimens from atopic subjects without asthma and normal control subjects and relationship to bronchial hyperresponsiveness. J Allergy Clin Immunol 1991; 88: 661-674.

14. Djukanovic R, Lai CKW, Wilson JW, et al. Bronchial mucosal manifestation of atopy: a comparison of markers of inflammation between atopic asthmatics, atopic nonasthmatics and healthy controls. Eur Respir J 1992; 5: 538-544.

15. Foresi A, Leone C, Pelucchi A, et al. Eosinophils, mast cells, and basophils in induced sputum from patients with seasonal allergic rhinitis and perennial asthma: relationship to methacholine responsiveness. $J$ Allergy Clin Immunol 1997; 100: 58-64.

16. Braman SS, Barrows AA, DeCotiis BA, Settipane GA, Corrao WM. Airway hyperresponsiveness in allergic rhinitis: a risk factor for asthma. Chest 1987; 91: 671-674.

17. Settipane RJ, Hagy GW, Settipane GA. Long term risk factors for developing asthma and allergic rhinitis: a 23 year follow up of college students. Allergy Proc 1994; 15 : 21-25.

18. D'Amato G, Ruffilli A, Sacerdoti G, Bonini S. Parietaria pollinosis: a review. Allergy 1992; 47: 443-449.

19. Louis R, Shute J, Biagi S, et al. Cell infiltration, ICAM-1 expression, and eosinophil chemotactic activity in asthmatic sputum. Am J Respir Crit Care Med 1997; 155: 466-472.

20. Pin I, Radford S, Kolendowicz R, et al. Airway inflammation in symptomatic and asymptomatic children with mehacholine hyperresponsiveness. Eur Respir J 1993; 6: 1249-1256.

21. Spanevello A, Migliori GB, Sharara A, et al. Induced sputum to assess airway inflammation: a study of reproducibility. Clin Exp Allergy 1997; 27: 1138-1144.

22. Perng W-D, Holgate ST, Walls AF. Mast cell tryptase as a stimulus for cytokine production and release from epithelial cells: the role of PAR-2. Immunology 1998; 95: 20.

23. Rahman I, MacNee W. Role of transcription factors in inflammatory lung diseases. Thorax 1998; 53: 601-612.

24. Stadnyk A. Cytokine production by bronchial epithelial cells. FASEB J 1994; 8: 1041-1047.

25. Calderon MA, Devalia JL, Prior AJ, Sapsford RJ, Davies RJ. A comparison of cytokine release from epithelial cells cultured from nasal biopsy specimens of atopic patients with and without rhinitis. Allergy Clin Immunol 1997; 99: 65-76. 
26. Salvi S, Semper A, Blomberg A, et al. Interleukin-5 production by human airway epithelial cells. Am J Respir Cell Mol Biol 1999; 20: 984-991.

27. van Veizen E, Van den Bos JW, Benckhuijsen JAW, van Essel T, de Bruijn R, Aalbers R. Effect of allergen avoidance at high altitude on direct and indirect bronchial hyperresponsiveness and markers of inflammation in children with allergic asthma. Thorax 1996; 51: 582-584.

28. Wen L-P, Fahrni JA, Matsui S, Rosen GD. Airway epithelial cells produce stem cell factor. Biochim Biophys Acta 1996; 1314: 183-186.

29. Gleich GJ. The eosinophil and bronchial asthma: current understanding. J Allergy Clin Immunol 1990; 85: 422436.
30. Holgate ST, Church MK, Polosa R. Adenosine: a positive modulator of airway inflammation in asthma. Ann NY Acad Sci 1991; 629: 227-236.

31. Polosa R, Renaud L, Cacciola R, Prosperini G, Crimi N, Djukanovic R. Sputum eosinophilia is more closely associated with airway responsiveness to bradykinin than methacholine in asthma. Eur Respir J 1998; 12: 551-556.

32. Ronchi MC, Piragino C, Rosi E, et al. Do sputum eosinophils and ECP relate to the severity of asthma. Eur Respir J 1997; 10: 1809-1813.

33. Rossi AG, Haslett C, Hirani N, et al. Human circulating eosinophils secrete macrophage migration inhibitory factor (MIF). Potential role in asthma. J Clin Invest 1998; 101: 2869-2874. 